\title{
Research on the Classifications and Characteristics of Viral Advertisements
}

\author{
Xiaolun Jia \\ School of Economics and Management, Beihang University, Beijing, 100191, China
}

Keywords: Viral advertisement, Viral marketing, Classifications and characteristics

\begin{abstract}
Viral advertisement, which has novel content, simple form, is wide spreading in the internet. The voluntary dissemination of the advertisement makes the advertising information spread like a virus and finally achieves the goal of marketing. The dissemination model of viral advertisement changes the model of the netizen to acquire and communicate information, and influence people's life imperceptibly. This paper focuses on the concept, classifications and main features of viral advertainments to provide some references for the relevant researchers.
\end{abstract}

\section{Introduction}

Network advertisement is a kind of high-tech advertisement, which uses professional banners, text links and multimedia methods to publish or advertise in the internet and pass it to the internet users. Network advertisement uses the digital technology to integrate traditional advertising into the network, allowing advertisers to advertise on the platform. Viral web advertising refers to the traditional network advertising that contains brand and product information embedded in the virus information, so that the audience actively sharing to achieve rapid and large-scale online advertising platform. Viral advertising, will implant the virus information and products of the two parts, implantation of the virus can attract the audience actively spread, contribute to implantation of the brand or product information for the promotion of the product or brand, both are indispensable. Viral advertising is a combination of online advertising and viral marketing. Viral marketing is not really the way to spread the virus marketing, but through word-of-mouth propaganda network users, information spread like a virus and spread, spread to thousands and millions of fast copies the audience. Viral marketing has become the most unique means of advertising online marketing, the public will be transferred to other readers of information, thereby rapidly expanding the impact of the product. The emergence of viral advertising breaks the traditional advertising pattern, effectively reducing the users in an online advertising in the process of making sense of conflict, more users can take the initiative to the advertisement content spread, advertisers can help to enhance the brand value with the objective of minimum cost. Therefore, viral advertainment has become an important part of today's advertisement.

\section{Classifications of Viral Advertisements}

Text Viral Advertisements. Text advertisement is a form of communication in which words are written to the public, to advertise goods, to advertise services, and to inform problems. There is no fixed pattern in the wording of the written advertisement, and the specific wording should be chosen according to the content, purpose, form and so forth of the advertisement. For example, the commodity advertisement should generally contain the name of the goods, features, after-sales service, user evaluation. However, in actual work, the specific content should be written in accordance with the form of advertisement, audience, location, the place should be as simple as possible, the details of the place should be as detailed as possible. In a word, a phrase, or even a word, it is much better to use it than the flowery ones. The writing of written advertisements should be true, 
concise and vivid, the most important of which is authenticity, which is the primary criterion. Those false text advertisements may bring short-term results, but in the long run, it is not conducive to the sustainable development of enterprises. Text virus advertisement should also write the name, time, and contact information in the right place so that it can win the trust of the audience, otherwise it will be treated as a false advertisement. Viral advertisement is expressed in words, mainly reflecting the product's interesting, unknowable and so on. The more interesting it is, the more interesting it is to inform people. Such advertisements are generally deliberately manufactured and transmitted by the enterprises, and some are transmitted by accidental factors. In any case, the ultimate purpose of advertisement is to promote the positive image of the enterprise, and ultimately to fix the position in the audience's mind.

Image Viral Advertisements. The image advertisement is composed of words and graphics, which has better vision and figurativeness. The image expression of the viral advertisement is defined in a moment of rest in the scene, readability in the form of authenticity, visual intuitive, light and contrast to attract the audience to get the reader's identity. It combines the personality of the business and the commonness of the art, and makes it easy for the audience to accept the characteristics of visual communication. Many of its characteristics have advantages in the dissemination But, it is the dissemination of commodity information, and promote the circulation of commodities. Because of the strong form beauty and form beauty to the outside world, the image expression form is far superior to the writing. In the actual use, many viral advertisement contents are the combination of text and images, take advantage of the two, make up for the shortcomings of the two, by fans love. Images of viral advertisements are more intuitive than text classes, because they are vivid and often give consumers a good laugh or shine. The landscape features a beautiful image and a breathtaking theme. The use of viral advertisements in images is mainly made in the name of an enterprise, made into a postcard, or acts as a desktop background for a computer. Watermark images, as the name suggests, add the name of the enterprise or logo at the bottom of the image. Of course, the effectiveness of the watermarked image only works when the consumer has specific needs. In the past, people watch the comedy movies or videos only through TV or movies, now through convenient internet. The user can not only see the same humorous images. Many users can see their creative upload funny images. This not only can break the user's depressed mood, produce relaxed mood, and but can also create dramatic and playful visual communication effect.

Video Viral Advertisements. Video advertisement can be divided into two categories: traditional video advertisement and mobile video advertisement according to the different carriers. The traditional video advertisement is to set up and launch advertisements in the video, while mobile video advertisement is a video slot model in mobile devices. The audiences can express their opinions through the reply way, also may transmit the information in the bigger scope through the sharing and the forwarding way. When you make Wechat video advertisement, you can combine brand elements with product information and show them in a proper way. At the same time, in advertisement marketing strategy, we must pay attention to ways and means. Some companies like to use viral video marketing advertisement tactics, which, if properly designed, can have unintended effects and can be costly if they fail. As we all know, video advertisement is a powerful place in the dissemination of accurate. We will make the audience interested in watching the video, and then by followers into share, and dissemination of the object as he is bound to have a characteristic of interest, this series of process is in the dissemination of accurate screening of the target consumers. The audience saw some classic and interesting, easy video is always willing to take the initiative to share, through voluntary information dissemination enterprise brand audience, the video will take the product information on the internet a lot of repeat, like a virus spreading. The key to viral video advertisement is the need for a valuable, meaningful, content that resonates with audiences. The online viral video advertising is the main way to pay through advertising, to Internet video communication carrier, will deliver attractive products or services provided by the information to the target audience, they will stimulate the products or services provided by the information initiative, quickly and effective transfer to a form of advertising online viral video advertising others are a form of online advertising, is a commercial 
act, it is required to pay. Virus video is not always possible. It can be commercial or non-commercial. Viral web video advertising must take video in the Internet as a carrier, which is one of the reasons why it is called online video advertising. The content of the ad delivered is attractive, not bland. If the information of the advertisement is not attractive, the audience will not actively spread it. There are events, video advertisement, marketing strategies. The event advertisement has been a hot topic of the audience. There are many brands are currently doing something in the event advertisement. This kind of advertisement also needs to plan influential events, make up a meaningful story, and then take this event as video. It inserts the product information into the event, and then become the event viral advertisement. In practice, the video advertisements with event content are more likely to be accepted and transmitted by the internet users.

\section{Characteristics of Viral Advertisements}

Creativity. Viral advertisement is popular because the content of the advertisement touches people's nerves and arouses great interest. The key to the success of the viral video is its own interest and entertainment, as well as the visual impact that attracts the eye, because it is the most intuitive form of presentation. Fun can make people happy, and the pursuit of happiness is human nature. The importance of content lies not only in the Internet, but also in traditional advertisement. The quality of a TV advertisement is determined by the preferences of the audience, and what the audience decides is the content of the advertisement, the originality of the advertisement, and whether the advertisement can move and attract the consumers. As the online viral video advertisement based on this network platform, inherited the traditional television advertisement advantage of new forms of advertisement, advertisement content is more is to decide the depth and breadth of advertisement communication effect and influence. Curiosity is the innate psychological quality and thinking form of human beings. The process of human growth is, in fact, the process of constant release and satisfaction of curiosity. The environment has always been extremely mysterious to mankind, accompanied by the disappearance of the original mystery, and a new mystery, new curiosity re confusing people. The process of expectation, release and satisfaction of curiosity is a process in which human beings know and explore the mysteries of nature, master and utilize the laws of nature, and promote the continuous progress of human society. Therefore, it fundamentally determines the pursuit of new psychology and thinking, which becomes the human nature. Some online advertisement, which has the innovative elements, can satisfy the user's curiosity, and be spread widely like a crazy virus. All the viral advertisements are rich in creativity to some degree.

Conciseness. To make the viral network video advertisement can be accepted and spread quickly by the audience, the content must be concise and clear, which is the inevitable choice under the complicated and diverse information dissemination environment. In today's era of information explosion, the pace of life in modern society is speeding up, and people's mental fatigue is increasing. In the face of overwhelming impact of information, people cannot accept all the information as before, they are more willing to choose the uptake of intuitive and simple, image information, visual senses are placed in a very important position. In the Internet, the autonomy of advertisement clicks increases the user's freedom, so it does not guarantee that the network users have enough time and patience to watch videos. Under such a large audience, even viral web video ads can better attract their audiences in terms of advertisement content. Traditional advertisement methods have some insurmountable defects, such as strong information interference, complex reception environment, audience alert, serious psychological conflicts and so on. But in viral advertisements, the viral factors that the audience receives tend to be very attractive. As the initiative of the audience and the interaction rate with advertisers increase, it will make the audience free of charge as a virus disseminator, making the reliability of the virus information is much higher than traditional media information. At the same time, the receiving channels of viral marketing are more private, such as mobile phone text messages, e-mail, closed forums and so on, which will increase the reception rate of virus information. Simple content is the basis of viral advertisement. 
Dissemination. The spread advertisement of viral advertisement is its main characteristic. Traditional media advertisement is usually one-way, and the promotion of viral advertisement is divergent. The audience to accept the information of the product, and then other audience product information transmission to the associated, and continue to be the target audience into information free promotion, so the cycle, which formed a continuous double growth pattern, so the wide spread viral advertisement is many to many communication networks. The audience is no longer a single group that accepts information, and the subject of publishing and disseminating information is no longer a single media organization. With the diffusion of new media and new technologies, people have entered the era of self-media, and individuals have information dissemination platform, just as they have their own media, which can transmit information to most or specific groups. And with the rise of the new model, users can advertise their own preferences on the Internet platform. This new advertisement model is highly subversive to traditional advertisement. The wide spread viral advertisement is accomplished through the initiative and enthusiasm of the audience, reducing the audience tired of psychology, greatly enhance the communication effect and credibility, which would reduce the unfavorable factors in the process of information transmission, make advertisement communication more smoothly. The two-way communication of information makes possible the interaction of viral advertisement. This is not only reflected in the interaction between the enterprise and the audience, but also reflected in the interaction between the audience and the audience. The audience has got rid of the passive acceptance in the traditional mass communication, and brought about its individuality and democracy. In the network communication, the role of the audience is further enhanced. At the same time, it receives the information and begins to act as the communicator. It can share the information with the friends and relatives around the network. This is also the viral network video advertisement this kind of emerging network advertisement form can develop the motive.

\section{Conclusion}

Viral advertising is an inevitable trend in the development of the internet. If the enterprise can grasp the viral marketing of product advertisement, it will be able to achieve the goal of successful marketing with low cost and high return. The incorrect use of viral advertising may also have a bad impact on the corporate brand and reduce the reputation of the enterprise. When making online viral video advertising, we should avoid vulgar tendency and balance the good communication effect and the enhancement of the brand reputation.

\section{References}

[1] Chang Yingzheng. The Present Situation and Development Trend of the Network Advertisement Market in China [J]. Value Engineering, 2014(20): 163-164.

[2] Sun Lin. On the Viral Video Aderising Network Development [J]. The Science Education Article Collects, 2011(7): 205-206.

[3] He Junhui. Network Advertisement Incentive Basedon Click Stream Model [J]. Chinese Journal of Management, 2014, 11(6): 883-888.

[4] Ma Rui, Chen Xiaoyu. The Communicaiton Strategy Analysis on the Internet Viral Vedio Advertisment [J]. Journal of Hebei University of Economics and Business (Comprehensive Edition), 2013, 13(4): 12-14. 